\title{
Finite Element Analysis of a Transtibial Prosthesis for a Paralympic Cyclist
}

INGENIERÍA MECÁNICA

\section{Análisis por elementos finitos de una prótesis transtibial para un ciclista paralímpico}

\author{
Jhonnatan E. Zamudio ${ }^{1 \S}$, Daniel Guzmán ${ }^{1}$, Natalia Sánchez ${ }^{1}$, Oscar L. Mosquera1, Daniel \\ A. Botero ${ }^{2}$, Oscar Rubiano ${ }^{3}$, José A. García ${ }^{1}$, Cristhian C. García ${ }^{1}$, Juan C. Valencia ${ }^{1}$ \\ ${ }^{1}$ Escuela Militar de Cadetes “General José María Córdova”, Grupo de investigación en Ingeniería y \\ Simulación, Bogotá, Colombia \\ ${ }^{2}$ Universidad de la Sabana, Grupo de investigación Proseim, Bogotá, Colombia \\ ${ }^{3}$ Universidad Santo Tomás, Grupo de investigación GICAEDS, Bogotá, Colombia

\begin{abstract}
§jhonatan.zamudio@esmic.edu.co,daniel.guzman@buzonejercito.mil.co,nathasan97@hotmail.com, oscar.mosquera@esmic.edu.co,daniel.botero@unisabana.edu.co, oscarrubiano@usantotomas.edu.co,
\end{abstract} \\ jose.garcia@buzonejercito.mil.co,cristhian.garcia@esmic.edu.co,juan.valencia@buzonejercito.mil.co
}

Recibido: 26 de noviembre 2019 - Aceptado: 14 de enero de 2020

\begin{abstract}
Currently, finite element analysis techniques are used to reduce costs in the manufacturing process of sports prostheses. This study primarily focuses on the finite element analysis of a design for a transtibial prosthesis for a paralympic cyclist, integrating the biomechanics of an athlete with a double leg amputation below the knee with two prostheses categorized before the Union Cycling International (UCI) with a C-3 disability and the characteristics of the terrain and the dynamic model. The analysis employing finite elements aims to evaluate the static and dynamic behavior of the proposed design when subjected to competition in the track-cycling category. As a result of this analysis, mechanical aspects, such as static forces, buckling, frequency, fatigue, free fall, impact, and aerodynamics, can be evaluated to verify that the design of the proposed transtibial prosthesis meets an adequate aerodynamic profile and its mechanical characteristics are suitable to be used in a high-performance Paralympic cycling competition.
\end{abstract}

Keywords: Aerodynamics, Dynamic model, Finite elements, Paralympic cyclist, Transtibial prosthesis. 


\section{Resumen}

En la actualidad se emplean técnicas de análisis por elementos finitos para reducir costos en el proceso de fabricación de prótesis deportivas. Este estudio particularmente se centra en el análisis por elementos finitos de un diseño para una prótesis transtibial de un ciclista paralímpico, en el que se integra la biomecánica de un atleta con amputación en ambas piernas por debajo de la rodilla, con dos prótesis categorizado ante la Unión Ciclista Internacional (UCI) con una discapacidad de grado C-3, considerando características del terreno y el modelo dinámico. El análisis por medio de elementos finitos tiene como objetivo evaluar el comportamiento estático y dinámico del diseño propuesto cuando se somete a una competencia en la categoría de ciclismo de pista. Como resultado de este análisis, se pueden evaluar aspectos mecánicos como: esfuerzos estáticos, pandeo, frecuencia, fatiga, caída libre, impacto y aerodinámica, permitiendo verificar que el diseño de la prótesis transtibial propuesto cumple con un perfil aerodinámico idóneo y sus características mecánicas para ser utilizada en una competencia de ciclismo paralímpico de alto rendimiento.

Palabras clave: Aerodinámica, Ciclista paralímpico, Elementos finitos, Modelo dinámico, Prótesis transtibial.

\section{Introduction}

Today's lower limb prostheses are designed to be lightweight, versatile, and adjustable. Custom socket designs are used to provide greater stability, better grip, and ergonomics at the point of contact with the skin. Because the socket is the most important prosthetic device for a highperformance athlete, it is necessary to optimize its design using finite element analysis techniques $^{(1)}$.

The selection of materials for the manufacture of prostheses must be considered, as it plays a vital role in durability, mechanical properties, and costs. In Latin America, the use of carbon fiber, fiberglass, and Kevlar reinforced plastics for the manufacture of prostheses and orthoses has increased because of their high mechanical properties $^{(2)}$.

The cyclist's kinematic analysis should also be considered, as it allows characterizing time and space factors of the prosthesis' movement, among them, displacement, time, speed, and acceleration, factors that are important for the cyclist's sports performance. It also enables the optimization of factors, such as mechanics, energy transfers, and aerodynamics, without exceeding the limits established by the
International Cyclist Union (ICU). Any modification, no matter how small, can cause variations in the drag force of the Paralympic cyclist, generating a higher or lower expenditure of energy in high-performance competition ${ }^{(3)}$.

It is essential to know the dynamic model that a Paralympic cyclist experiences in a track cycling competition to achieve the optimal design of a transtibial prosthesis. This model allows us to obtain the starting point for the kinematic and aerodynamic design of the lower limb prosthesis that can be used in high-performance Paralympic competitions $^{(4)}$.

Furthermore, the use of the finite element analysis is a fundamental tool to optimize product design and manufacturing processes ${ }^{(5)}$, and guarantee a feasible, practical, ergonomic, and appealing design. This technique allows the identification of a product's different mechanical characteristics, saving time and money, which can be used for the construction of a functional prototype, as simulations provide highly accurate results to validate the geometry of the proposed designs in a real environment ${ }^{(6)}$. In this case, static analysis, frequency study, topology study, buckling, fatigue, drop, and aerodynamics analyses were carried out using the finite element analysis technique. 
SolidWorks was used in the CAD (ComputerAided Design) modeling of a socket for a transtibial prosthesis to be used in highperformance competitions in Paralympic cycling. However, for the study of finite elements, the SolidWorks Simulation module was used, and the aerodynamic analysis of the socket was performed using CFD (Computational Fluid Dynamics) technology in SolidWorks Flow Simulation.

The methodology followed was the creation of a conceptual design, a preliminary design, and a detailed design. CAD designs were produced to evaluate the designs using the finite element analysis technique. The results obtained were analyzed, and the design of the most viable socket for an athlete with a double amputation of the lower legs categorized C3 before the International Cycling Union (ICU) is $\operatorname{proposed}^{(7)}$. Lastly, the conclusions and potential for future works are presented.

\section{Methodology}

This study approaches the design of a socket (the hard part) for a biomechanical and aerodynamic lower limb prosthesis, which will improve the performance of a Paralympic cyclist. Figure 1 shows the methodological course of the different stages considered, the conceptual design, preliminary design, detailed design, CAD design, and Finite Element Analysis. It synthesizes the execution of the finite element analysis of the socket of a transtibial prosthesis to determine whether the design is optimal, considering that this socket will be used by a high-performance grade C-3 disabled Paralympic cyclist.

\subsection{Conceptual design}

The conceptual design is a fundamental part of the manufacturing process in a prototype or product. In this stage, the requirements and needs of the client-user are identified to address key aspects for the final design ${ }^{(8)}$. Thus, the basic need and fundamental aspects were identified to guarantee the functionality and applicability of the socket for a transtibial lower limb prosthesis. To this end, an interview with a highperformance Paralympic cyclist was conducted to layout the research project, which was carried out by means of two techniques QFD (Quality Function Deployment) and PDS (Product Design Specification).

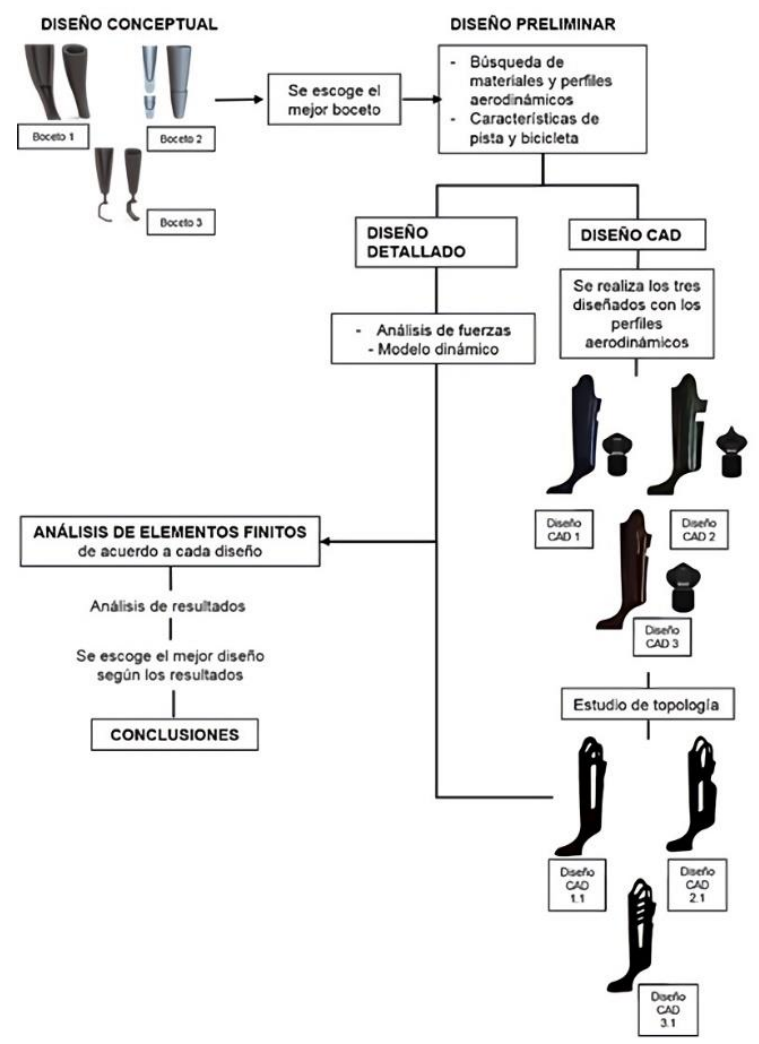

Figure 1. Methodology for finite element analysis of a socket

\subsubsection{Identification and layout}

An interview was carried out to identify the user's needs and expectations. It was determined that the cyclist has a bilateral transtibial disability caused by burns and amputation. His use of different prostheses established that improved must be made regarding weight and aerodynamics. The QFD, also known in Spanish as Despliegue de la Función de Calidad (Quality 
Function Deployment) is a tool that provides a systematic route for the process of developing a product or research. It establishes a link between the customer and end-user and the technical requirements that may trigger the development of the product or research ${ }^{(9)}$. Figure 2 shows the systematic path and the design specifications that were obtained for the development process of the socket of a transtibial prosthesis, which will provide the guidelines to invest in human resources and time. It develops each module according to its importance, so that, the main modules of this research correspond to those shown in Figure $2 \mathrm{a}$ and Figure $2 \mathrm{~b}$, which describe the general aspects that were taken into account for the development of the PDS (Product Design Specification) using the Brief model and applying it to all the modules established by the QFD $^{(10)}$.

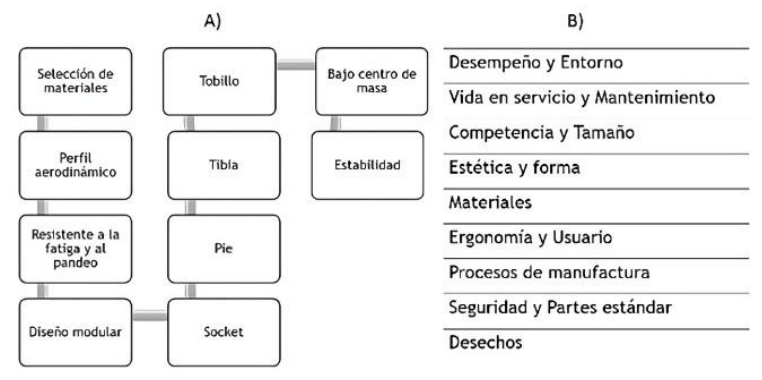

Figure 2. Systematic path according to $Q F D$ and $B$ ) Design specifications (PDS)

\subsection{Preliminary design}

This stage focuses on establishing a solution to the problem and determining the components and interactions that will allow an objective evaluation of the proposed design. It determines the specific shapes, proposed materials, and general designs, which represent the product or prototype as an organized set of parts, components, links, and couplings. ${ }^{(11)}$

Thus, three (03) sketches were produced considering the ease of manufacture, minimum number of pieces used, inclusion of an aerodynamic profile, ease of coupling between pieces, and minimum use of material. Each of the proposed designs is described in Figure 3.

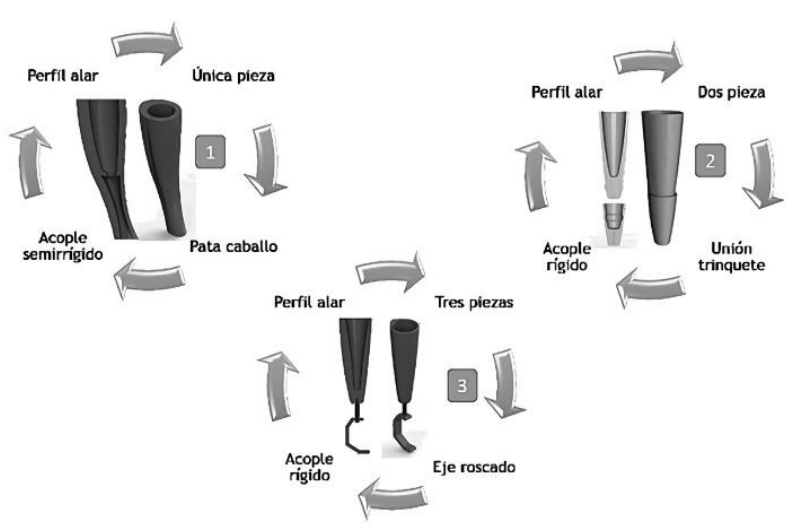

Figure 3. Designs proposed as alternative solutions.

Design \#1 is based on the lower end of a horse's leg, which is one (01) piece (Figure 3.1). It has an internal cavity with lower support for coupling with the subject's limb; the mechanical structure of the socket in the lower part is hollow to reduce weight and manufacturing costs. Design \#2 is a two-piece design (Figure 3.2). It uses a ratchet-type joint where the lower piece has a flange, and the upper piece has a coupling slot. This design also has an internal cavity with solid lower support for coupling with the person's residual limb. Design \#3 is a design based on four (04) pieces (Figure 3.3). These pieces are coupled by using a threaded shaft that fits directly into the socket, securing it with a self-blocking thread.

Then, a statistical analysis of the applied surveys was proposed to evaluate the previous sketches and select the best design. A sample of eight (08) people was used, considering their link and transcendency in the development of the prototype $^{(12)}$, to determine significant differences concerning the classification of the designs. Hypothesis testing was applied (sum of Wilcoxon ranges). 
Subsequently, the state-of-the-art was assessed. Two large groups of symmetrical and asymmetrical aerodynamic profiles were identified. Given that all airfoils have a standard of terms used to explain the main components that mathematically determine the behavior of the profile, we set out from the premise that an adequate coefficient to improve the aerodynamic behavior of the prosthesis must be less than 1 . Considering the previous, the state-of-the-art of different types of materials (Kevlar, glass, carbon fiber) used for the manufacture of prostheses was also performed. It was concluded that most of those existing in the market are made of carbon fiber. Therefore, we looked at the carbon fiber types that exist commercially according to their mechanical properties and number of filaments or threads that compose them $(1 \mathrm{~K}, 3 \mathrm{~K}, 6 \mathrm{~K}, 12 \mathrm{~K}, 24 \mathrm{~K} \text {, and } 50 \mathrm{~K})^{(13)}$.

This project is a case study. In a preliminary way, it shows how to find the "Dynamic model of a transtibial prosthesis for Paralympic

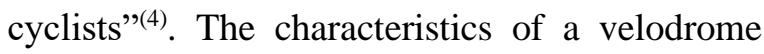
and the rules imposed by the International Paralympic Committee (IPC) were considered in the determination of this model. In this particular case, the dynamic model was determined using the characteristics involved in a track competition, such as the structure and shape of the Rio 2016 Olympic velodrome, the "CERVELO-T3" track bicycle, and a 3D scan of the C-3 disabled Paralympic cyclist's end socket.

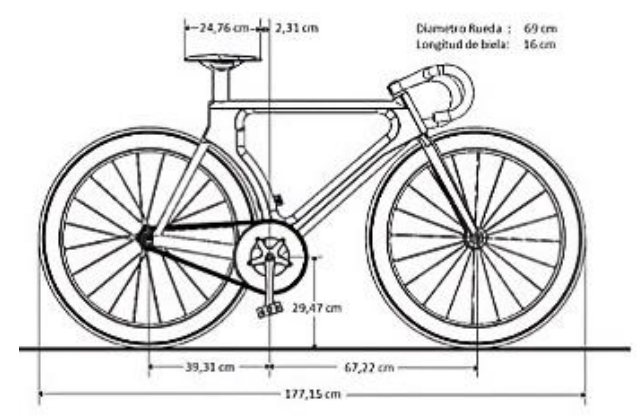

Additionally, to apply it to the dynamic model, the CAD design of the bicycle was completed, as shown in Figure 4, using the true dimensions of the track competition bicycle used by the Paralympic cyclist.

\subsection{Detailed design}

The detail design phase involved the production of all the specifications necessary for the production of the product ${ }^{(11)}$. Following the previous steps, it was decided that the dynamic model of the socket for the transtibial prosthesis should use the actual characteristics of the competition scenario, track bike, and biomechanics of the Paralympic cyclist. This was done to calculate the exertion experienced in a high-performance competition in the initial proposed design and to theoretically validate the allowable section module using the mechanical characteristics of a $3 \mathrm{k}$ carbon fiber material.

\subsubsection{Analysis using the Finite Element Analysis}

The FEM (Finite Element Method) has become a solution to predict failures caused by unknown stresses. It shows the issues of stress distribution in the material and allows designers to see all the stresses and forces involved ${ }^{(14)}$. Therefore, it was decided that topology, static analysis, frequency study, buckling, fatigue, drop, and aerodynamics studies should be performed.

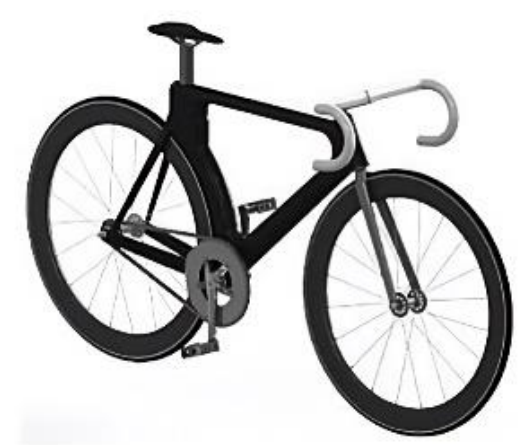

Figura 4. Diseño CAD bicicleta de pista "CERVELO T3" 
Table 1. Statistical analysis

\begin{tabular}{|c|c|c|c|c|c|c|c|c|}
\hline \multirow{2}{*}{ \# } & \multicolumn{3}{|c|}{ H1 } & \multirow{2}{*}{ Ho } & \multirow{2}{*}{ V.S.R } & \multicolumn{3}{|c|}{ VALUE-P } \\
\hline & $\mathbf{A}$ & B & C & & & A & B & C \\
\hline 1 & $\mu_{1}<\mu_{2}$ & $\mu_{1} \neq \mu_{2}$ & $\mu_{1}>\mu_{2}$ & $\mu_{1}=\mu_{2}$ & 89.5 & 0.9930 & 0.0190 & $0.0095 *$ \\
\hline 2 & $\mu_{1}<\mu_{3}$ & $\mu_{1} \neq \mu_{3}$ & $\mu_{1}>\mu_{3}$ & $\mu_{1}=\mu_{3}$ & 85 & 0.9705 & 0.0780 & $0.0390 *$ \\
\hline 3 & $\mu_{2}<\mu_{3}$ & $\mu_{2} \neq \mu_{3}$ & $\mu_{2}>\mu_{3}$ & $\mu_{2}=\mu_{3}$ & 70.5 & 0.6141 & 0.8244 & 0.4122 \\
\hline
\end{tabular}

\section{Results}

In the preliminary design, a statistical analysis of the applied surveys was made to evaluate the drafts presented in Table 1 to identify the differences between the sketches. It took into account three null hypotheses $(\mathrm{Ho})$ that there are no differences in the expected value of the score obtained from the evaluated sketches $\left(\mu_{1}=\mu_{2}\right.$, $\left.\mu_{1}=\mu_{3}, \mu_{2}=\mu_{3}\right)$, with their corresponding alternative hypotheses (H1-A, H1-B, H1-C). It was evident that Design \#1 achieved a significantly higher score than Design \#2 (pvalue $=0.0095)$, and Design \#3 ( $\mathrm{p}$-value = 0.0390).

Following the results obtained from the statistical analysis of the initial drafts, we proceeded to use Design \#1 to propose three (03) designs with a variation in their aerodynamic profile and perform the respective validations. However, this design cannot be compared with current models because the UCI's classification of category C3 competitors is based on functionality, not by the type of amputation. Thus, each design is exclusive to the competitor. Variations of the proposed aerodynamic profiles are shown in Figure 5.
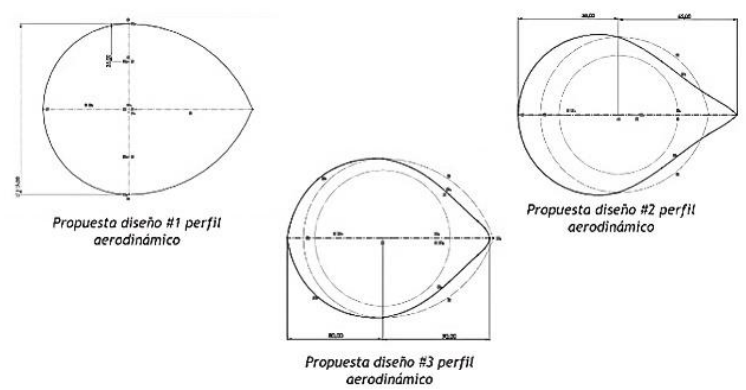

Figure 5. Proposed aerodynamic profiles
Based on the search of materials (Kevlar, glass, and carbon fiber), it was determined that the most suitable and widely used material for the manufacture of sockets for prostheses is the carbon fiber. This material can be found commercially in three woven patterns. Each one is different because of how they distribute the forces exerted, and their price by length or weight. However, all of them are CF sheets without epoxy thermosetting resin; this protection is applied after the thermoforming to provide higher duration, aesthetics, and waterproofing of the treated object. They can be obtained in the following patterns: Carbon fiber flat pattern $1 \times 1$, carbon fiber twill pattern $2 \times 2$, and carbon fiber 4 H SATIN pattern ${ }^{(15)}$.

Next, a theoretical validation was carried out, calculating the section module of each one of the proposed designs to verify if they were optimal or not. The mechanical characteristics of carbon fiber $3 \mathrm{k}$ were used to calculate the section module, obtaining a maximum permissible stress of $S u_{y}=228 M p a$, according to the shear force and bending moment diagrams (Figure 6) obtained from the dynamic model. It was determined that the minimum safety factor experienced by the proposed designs is 2.87 , implying that, theoretically, the three (03) proposed designs for the socket can withstand approximately three times the forces experienced in a track cycling scenario.

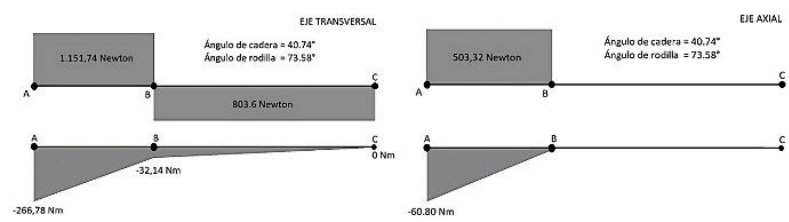

Figure 6. Shear force and bending moment diagram (Cross shaft - axial) 
Table 2. Mechanical characteristics of the materials used in the simulation. ${ }^{(18)}$

\begin{tabular}{lccc}
\hline \multicolumn{1}{c}{ Mechanical property } & 3K carbon fiber & 6K carbon fiber & 12K carbon fiber \\
\hline Elastic limit & $228 \mathrm{Mpa}$ & $241 \mathrm{Mpa}$ & $290 \mathrm{Mpa}$ \\
\hline $\begin{array}{l}\text { Maximum displacement } \\
\text { allowed }\end{array}$ & $1,2069 \times 10^{-1} \mathrm{~mm}$ & $1,2758 \times 10^{-1} \mathrm{~mm}$ & $1,5352 \times 10^{-1} \mathrm{~mm}$ \\
\hline $\begin{array}{l}\text { Elastic limit by fault } \\
\text { theorem with maximum } \\
\text { distortion energy. }\end{array}$ & $131,55 \mathrm{Mpa}$ & $139,05 \mathrm{Mpa}$ & $167,33 \mathrm{Mpa}$ \\
\hline
\end{tabular}

\subsection{CAD design and finite element analysis}

In the previous sections, we talked about aerodynamic profiles and material selection; this, for the creation of the materials in SolidWorks and to produce the CAD design with each one of the alternatives in its aerodynamic profile.

Three (03) preliminary CAD designs are proposed to begin the analysis by finite elements in order to determine which of the designs is optimal, according to the mechanical characteristics of the socket design. In Figure 7, with the help of the PhotoView360 ${ }^{(16)}$ tool. The renderings of each of the three (03) designs are shown.
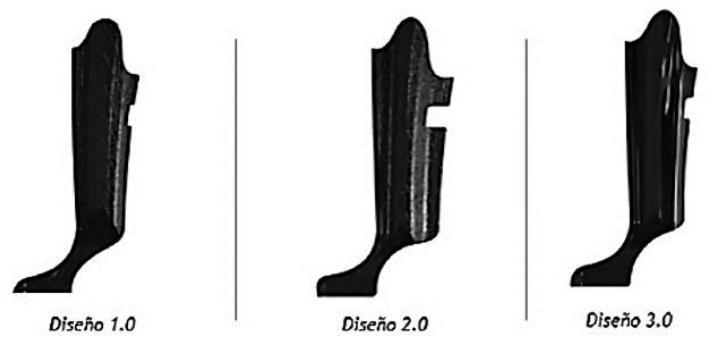

Figure 7. CAD designs proposed according to the variation of the aerodynamic profile. Created by the authors.

We based our evaluation of the proposed transtibial prosthesis socket designs on the Colombian technical standard NTC 4424-3 and the opinions proposed by the World Health Organization WHO in the Orthoprosthetic Standards. Eight (08) studies were carried out using simulation based on finite elements using SolidWorks software ${ }^{(17)}$. The information was used following the characteristics provided by the $3 \mathrm{~K}, 6 \mathrm{~K}$, and $12 \mathrm{~K}$ carbon fiber mode manufacturers. In order to obtain true results in the simulation, the materials were created in SolidWorks, considering the carbon fibers' mechanical properties. Table 2 shows the mechanical properties of the materials used in finite element analysis.

\subsubsection{Topology study}

This study allows for the redesign of an existing part to reduce the weight and improve performance (better strength-to-weight ratio) of the parts ${ }^{(19)}$. Figure 8 shows the three (03) new designs suggested by this study, evidencing the difference in weight of each of the designs.

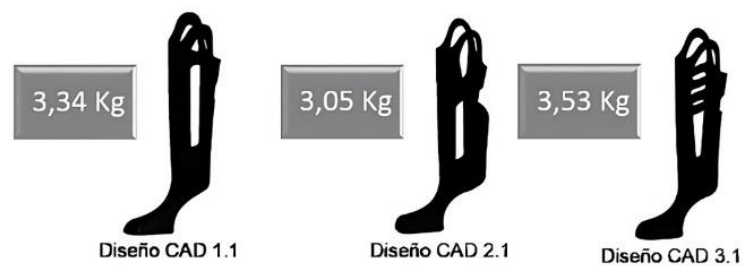

ESTUDIO DE TOPOLOGÍA

(REDUCCIÓN MASA)

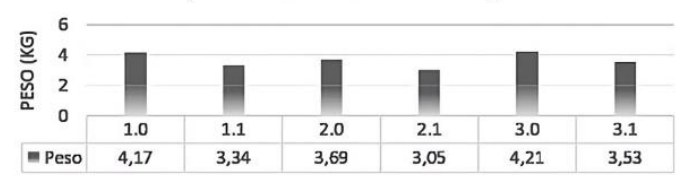

\section{Diseño 2.1 Diseño 3.0}

Figure 8. Topology study results

\subsubsection{Static analysis}

This analysis allows us to evaluate the safety factor to redesign and avoid malfunctions in the 
most desirable areas. That is, it provides the minimum and maximum values where the design and the material that have been chosen may falter, thus showing the results of stresses that exceed the elastic limit of the material and the stresses that are generated ${ }^{(20)}$. In this case, the mechanical parameters of maximum stresses, maximum displacement, and safety factors were analyzed. Figure 9 shows the analysis obtained, according to the best and least optimal design. The results showed that Design 3.0 in $12 \mathrm{k}$ carbon fiber has the best performance, achieving the support of up to 1.888 .46 Newton. In contrast, Design 1.0 in $3 \mathrm{k}$ carbon fiber supports up to 1.358 .08 Newton.

A)

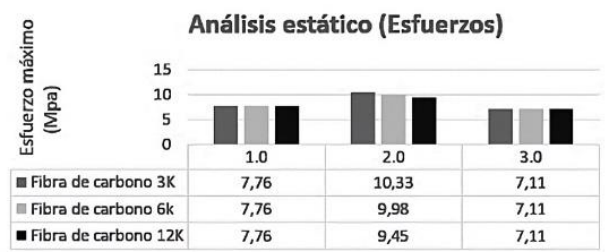

B)

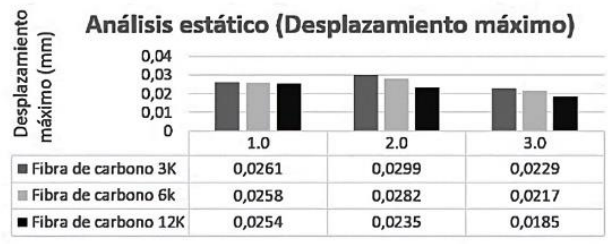

C)

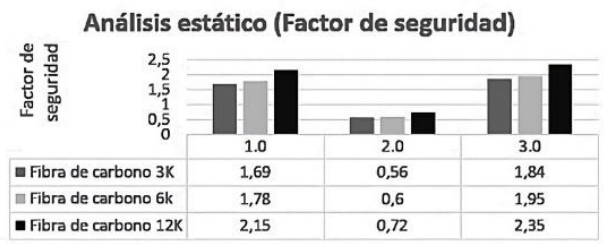

Figure 9. Results of the Finite Element Static Analysis

\subsubsection{Frequency study (Fundamental Natural Frequencies)}

Structures have a tendency to vibrate at specific frequencies called natural or resonant frequencies (21). Each natural frequency is associated with a particular shape called a modal shape, which the model tends to adopt when vibrating at that frequency. With the aid of the
SolidWorks software, the basic modal shapes of vibration were determined according to the geometry of each socket design. In this study, the response in amplitude and natural frequencies were considered, according to the clamping point parameters and the radius of curvature. The results are shown in Figure 10. Design 1.0 in $12 \mathrm{k}$ carbon fiber shows better performance to enter resonance frequency. Design 2.0 in $3 \mathrm{k}$ carbon fiber is the least optimal because its fundamental frequency is the lowest.

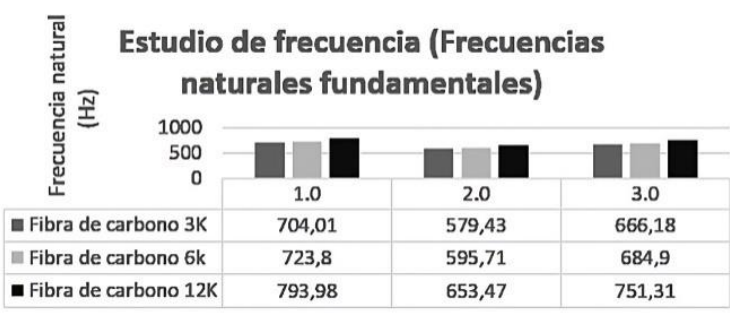

Figure 10. Results of the frequency study by finite element

\subsubsection{Buckling}

Buckling is a sudden and marked displacement that occurs in thin sections caused by axial loads; a section can undergo different types of buckling under critical loads ${ }^{(22)}$. In this case, as can be seen in Figure 11, none of the designs had mechanical failure due to buckling because the safety factors are very high. However, Design 3.0 in $12 \mathrm{k}$ carbon fiber had the best performance, and Design 2.1 in $3 \mathrm{k}$ carbon fiber had the least.

\subsubsection{Fatigue}

Material fatigue is a phenomenon that occurs when cyclical amplitude loading over time causes the structure to break, yielding lower stress values than those that occur involving constant amplitude ${ }^{(23)}$. This study considered the load factor, percentage of damage, as well as and SN-curves. Figure 12 shows that Design 3.1 in $12 \mathrm{k}$ carbon fiber had the best fatigue behavior, and Design 2.0 in $3 \mathrm{k}$ carbon fiber was the least 
optimal. The percentage of damage over twelve (12) months corresponds to $34.59 \%$ of the socket when it is subjected to high workloads, during training, or competitions set for the highperformance Paralympic cyclist.

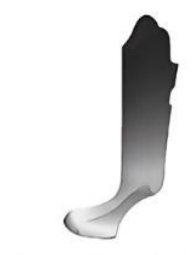

Respuesta amplitud diseño 1.0 Fibra de carbono $3 k$

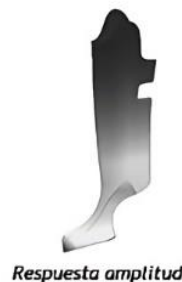

Respuesta amplitud diseño 2.0 Fit carbono $6 k$
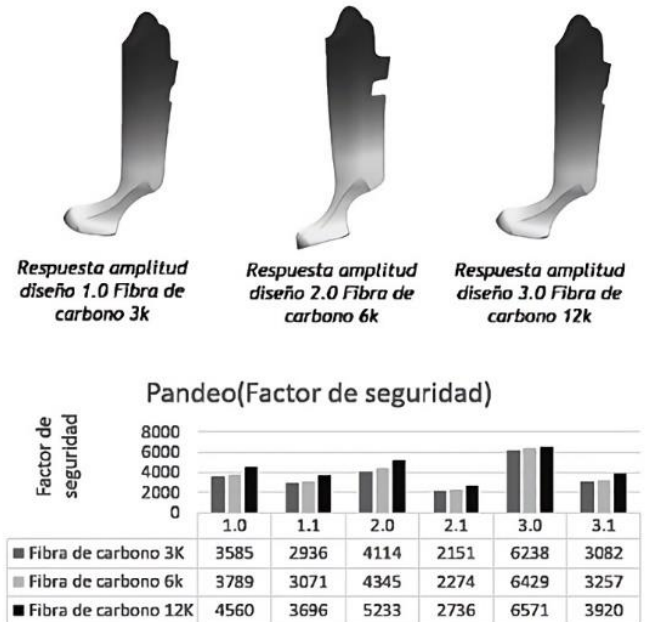

\section{Diseño 3.0}

\section{Diseño 2.1}

Figure 11. Results of the buckling evaluation by finite elements

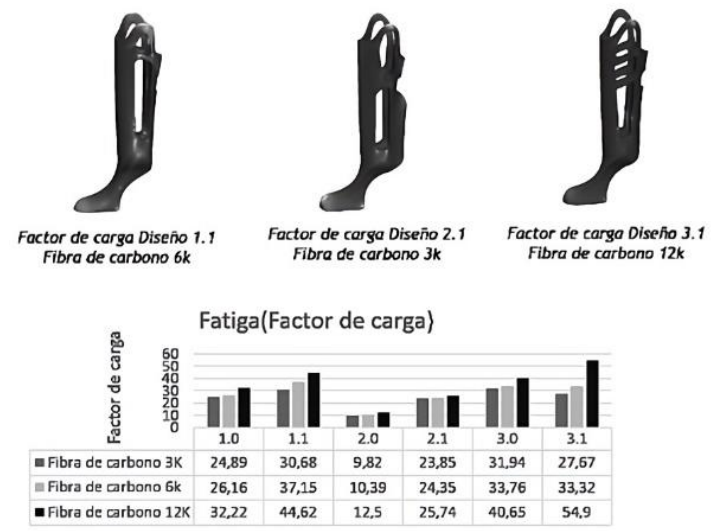

Diseño 3.1

Diseño 2.0

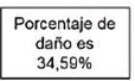

Figure 12. Results of fatigue analysis by finite elements.

\subsubsection{Drop}

This study considered the maximum displacement generated in the socket by a drop of approximately one meter high. Figure 13 shows the results. Design 1.1 in $12 \mathrm{k}$ carbon fiber had a better behavior to support deformations; Design 2.0 in $3 \mathrm{k}$ carbon fiber had the least.

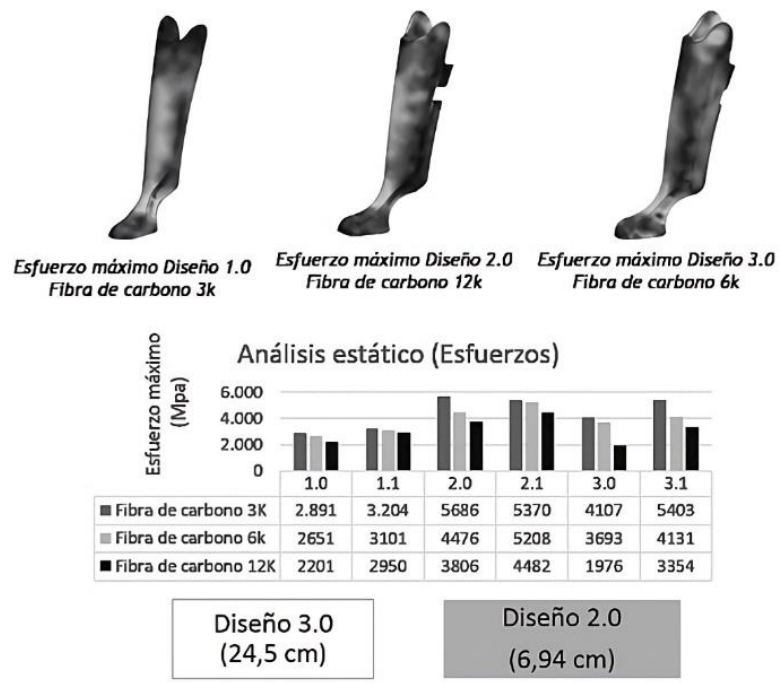

Figure 13. Drop analysis results by finite elements.

\subsubsection{Aerodynamics}

Aerodynamics is the part of mechanics that studies the relative motion between a solid and the surrounding fluid, usually air, thus determining the pressures and forces that are generated on a body ${ }^{(24)}$. An aerodynamic study was performed for each of the designs. The following parameters were determined according to the results obtained with the Paralympic cyclist in maximum effort tests.

- Atmospheric pressure $=101.325 \mathrm{~Pa}$

- Ambient temperature $=20^{\circ} \mathrm{C}$

- Flow rate $=60 \mathrm{Km} / \mathrm{h}=16.66 \mathrm{~m} / \mathrm{s}$

- Fluid used: air

- Study for exterior surfaces

- Volume analysis selection 
Then, aerodynamic studies were performed according to the behavior of the socket concerning speed, temperature, and pressure. The results obtained for each of the behaviors described above are shown in detail below:

\subsubsection{Velocity}

It was considered that the maximum velocity produced by each of the socket designs is provided by a wind current of approximately 60 $\mathrm{km} / \mathrm{h}$. It was determined that Design 2.1 had the best performance to turbulence, and Design 1.0 had the least because it increases the input speed, generating more turbulence; this is shown in Figure 14.
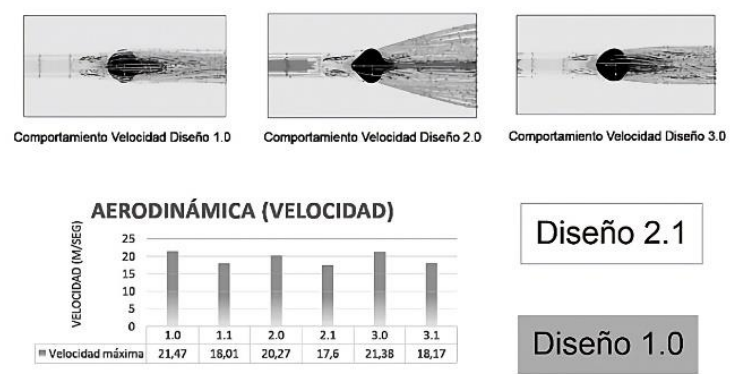

Diseño 2.1

Diseño 1.0

Figure 14. Aerodynamics results (velocity) by finite elements.

\subsubsection{Temperature}

Figure 15 shows that Design 2.1 had better wind friction heat dissipation performance and Designs 1.0-3.0 had the least heat dissipation.
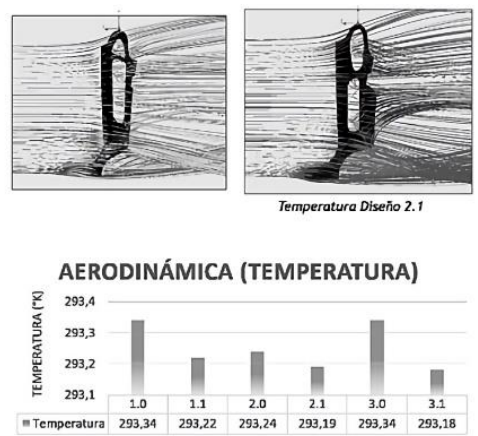

Figure 15. Aerodynamics results (Temperature) by finite elements.

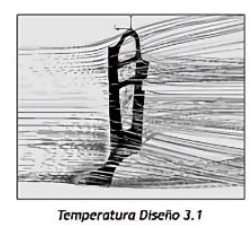

Diseño 3.1

Diseño 1.0 3.0
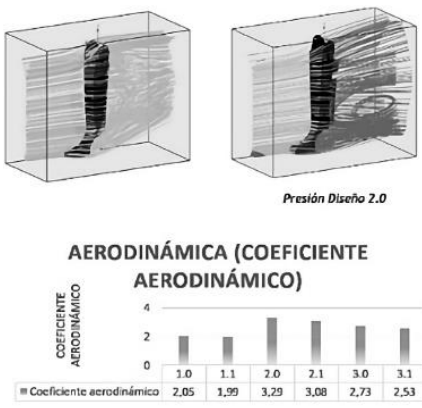

Diseño 1.1

Diseño 2.0
Figure 16. Aerodynamics results (Pressure) by finite elements and aerodynamic coefficient

\section{Conclusions}

In this work, different studies were carried using the finite element analysis technique to determine the mechanical properties of the designs proposed. The results can aid decisionmaking regarding the most viable design option for a Paralympic cyclist to obtain better sports performance and achieve the goals set during his competitive and high-performance season.

Based on the aerodynamic analysis presented, it can be concluded that the aerodynamic coefficient varies according to the geometry of each socket, generating a greater or lesser impact on the drag force that the Paralympic cyclist must overcome in timed track competitions, as this force is a fundamental variable in time loss or gain and, ultimately, in achieving the top positions in the competition. 
The design of these prostheses could be a predominant factor in improving an athlete's sports performance, not only with greater safety but also with efficiency when performing their own pedaling technique. Therefore, this prosthetic design, are a contribution to science in terms of engineering and physiology applied to the sciences of high-performance Paralympic sports, which generates a technological impact and promotes social inclusion at a national level.

This design will allow the National Army of Colombia to apply the methodology and implement it to all its members who have some type of disability and are Paralympic athletes in different categories of the Olympic Games.

\section{References}

(1) Ortopedia SM De. Determinación de esfuerzos en el socket de una prótesis transtibial por medio del método del elemento finito. Acta Ortopédica Mex. 2003;17(2):89-93.

(2) Karina B, Reyes V, Augusto C, Nuñez A, Mercedes A, Mora E, et al. Diseño de un encaje para prótesis de miembro inferior con amputación por encima de la rodilla. Rev Épsilon. 2007;19-28.

(3) García-López J, Peleteiro J, RodriguezMarrollo J, Córdova A, Villa-Vicente J. Valoración biomecánica de la resistencia aerodinámica en ciclistas profesionales: aspectos metodológicos. In: II Congreso Internacional de la Asociación Española de Ciencias del Deporte. Madrid: Asociación Española de Ciencias del Deporte; 2002.

(4) Zamudio JE, Mosquera OL, Guzmán D, Botero DA, Espinosa OR, García-Torres JA, et al. Modelo dinámico de una prótesis transtibial para ciclistas paralímpicos. In: II Congreso
Internacional en Inteligencia Ambiental, Ingeniería de Software y Salud Electrónica y Móvil - AmITIC 2018. Chiriquí, Panamá: Universidad Tecnológica de Panamá (UTP); 2018. p. 151-7.

Salafia J, Garcia B, Hormazábal PA, Dominguez C, Franco G, Giordano W, et al. Analisis estructural de bogie en tanque cisterna semirremolque. In: CAIM 2016 Congreso Argentino de Ingeniería Mecánica. Santiago del Estero, Argentina: Universidad Nacional del Nordeste; 2016.

(6) Kalpakjian S, Schmid SR. Manufactura, ingeniería y tecnología. 4th ed. México D.F.: Pearson Educación; 2002. 1294 p.

(7) Federación Colombiana de Ciclismo. Reglamento del Deporte Ciclista UCI [Internet]. 2017. Available from: http://www.federacioncolombianadeciclis mo.com/reglamento-uci/.

(8) Briede-Westermeyer JC, Cabello-Mora M, Hernandis-Ortuño B. Modelo de abocetado concurrente para el diseño conceptual de productos industriales. DYNA. 2014;81(187):199-208. Doi: dyna.v81n187.41068.

(9) Tamayo-Enríquez F, Bosh VG. ¿Qué es el QFD? Descifrando el Despliegue de la Función de la Calidad. México D.F.; 2004.

(10) García Díaz V, Núñez Valdez ER, Pascual Espada J, García Bustelo CP, Cueva Lovelle JM, Montenegro Marín CE. Introducción breve a la ingeniería dirigida por modelos. Rev Tecnura. 2014;18(40):127-142.

(11) Norton RL. Diseño de maquinaria. Vol. 4ta ed. México D.F.:McGraw-Hill; 2009. $747 \mathrm{p}$. 
(12) Silvente VB, Hurtado R. Classificació de

(19) Rodríguez Sánchez NP. Estudio proves no paramètriques. Com aplicar-les en SPSS. Rev d'Innovació i Recer en Educ. 2012;5(2):101-13.

(13) Siquerios M, Reyna M, Nuño V, Huegel J, Castañeda A. Metodología para la fabricación de una prótesis transtibial a base de material compuesto de fibra de carbono y resina epóxica Methodology for the manufacture of a transtibial prosthesis based on carbon fiber composite and epoxy resin. Revista Matéria. 2018;23(2): e-12095. Doi: 10.1590/s1517-707620180002.0482.

estructural del ala de un vehículo aéreo no tripulado para la optimización de su peso en el Centro de Investigación y Desarrollo de la Fuerza Aérea Ecuatoriana [dissertation]. Ambato, Ecuador: Universidad Téncia de Ambato; 2012. 209 p.

(20) Lizarza JTC. Método de los Elementos Finitos para Análisis Estructural. 4th ed. Tecnun, editor. San Sebastián, España: Universidad de Navarra; 2011. 287 p.

(21) Adrados JS. Diseño, fabricación, puesta en marcha y modelado de un sistema de simulación vibro- acústica de fallos en maquinaria rotativa [dissertation]. Bogotá, DC: Universidad de San Buenaventura; 2018. 151 p.

(22) McCormac JC, Csernak SF. Diseño de Estructuras de Acero. $5^{\text {th }}$ ed.Alfaomega, editor. México, D.F.:Pearson Education; 2012. $736 \mathrm{p}$.

Explained [Internet]. 2015 [Consulted 2020 Apr 15]. Available from: https://www.carbon.ee/en/n/carbon-fiberall-patterns-explained.

(16) SolidWorks Corp. PhotoView 360 SOLIDWORKS®. Suresnes, Francia: Dassault Systèmes, S.A; 2018.

(16) SolidWorks Corp. SOLIDWORKS®. Suresnes, Francia: Dassault Systèmes, S.A; 2018.

(23) Medina R, Salas M, Luco R, Bertram V. Análisis de estructuras navales mediante el método de elementos finitos. Síntesis Tecnológica. 2005;2(1):27-36. Doi: 10.4206/sint.tecnol.2005.v2n1-04.

(24) Mott R. Mecanica de fluidos. $7^{\text {th }}$ ed. Pearson Education; 2015. 644 p.

(25) Cerpa R, Nieto E, Londoño L. Turbulence models study in an external vehicle aerodynamics, using a computational fluid dynamics software. Actas de Ingeniería. 2016;2:168-75. 2020 Apr 15]. Available from: https://www.hexcel.com/user_area/conten t_media/raw/AS4_HexTow_DataSheet.p df. 